\title{
Use of Augmented Reality to Improve Specific and Transversal Competencies in Students
}

\author{
Esteban Vázquez-Cano \\ National University of Distance Education, Madrid, Spain \\ https://orcid.org/0000-0002-6694-7948 \\ Verónica Marín-Díaz \\ University of Cordoba, Córdoba, Spain \\ https://orcid.org/0000-0001-9836-2584 \\ Wellington Remigio Villota Oyarvide \\ Santiago de Guayaquil Catholic University, Guayaquil, Ecuador \\ https:/ / orcid.org/0000-0002-0081-4704 \\ Eloy López-Meneses \\ Pablo de Olavide University, Seville, Spain \\ https:// orcid.org/0000-0003-0741-5367
}

\begin{abstract}
Work in higher educational centres implicates the use of different types of methodology. The digital society demands students with a digital competence, and it is the responsibility of the university institution to ensure they succeed in obtaining it. This article presents an innovative immersive experience developed in a seminar on emerging technologies with 231 university students, and records their perceptions of some augmented reality apps used on the Social Education degree course and the Social Work and Social Education joint degree course at Pablo de Olavide University in Seville (Spain) in the academic years 2016-2018. A qualitative exploratory descriptive study was used to analyse the experience. The study presents the most important findings of this experience with augmented reality at the university, and proposes some didactic uses for the most interesting of these apps, with attention to their usability, ease of use and capacity to help early-stage learners to acquire new knowledge. Students considered that AR apps would provide educational scenarios that were more stimulating, collaborative and interactive, and would foment a more open type of education ( $N=159 / 68.8 \%)$. The principal conclusion is using this technology in the psychosocial treatment of problems could help social area professionals to sharpen their competences and, at the same time, reinforce support and improve the conditions and treatments of aspects identified in these at risk groups.
\end{abstract}

Keywords: Augmented reality; Specific and transversal competences; University students; Digital competence; App 


\section{Introduction}

The development of specific and transversal competencies in higher education is one of the fundamental objectives of the European Credit Transfer and Accumulation System (ECTS). This type of training approach in higher education subjects allows us to deal with things in a transversal and interdisciplinary way, such as content and skills for treatment, creation and dissemination, as well as the reflections and conclusions derived from the entire teaching-learning process. In this context, Augmented Reality (AR) emerges as a catalyst tool for content and competencies with great didactic potential. With $\mathrm{AR}$, we can design more enriched educational environments that bring the student closer to realities and situations in an immersive and video-simulated way, allowing them a greater understanding and reflection in inquiry in their learning. For this, it is necessary for teachers to acquire new roles that would enable didactics and evaluation under the new learning scenarios: tutor, counsellor, designer of mediated learning situations, evaluator, and content creator, among others. In this research, we propose and analyse new ways of dealing with content and competences in a combined way with the use of different augmented reality tools in higher education through the analysis of an educational experience at the Pablo de Olavide University (Seville / Spain).

\section{Augmented technology: new possibilities for innovation in education}

The technological imperative in education mirrors a more general evolution and digitalisation in society and the need to acquire new competences (Kettil, 2019). Today, the use of information and communication technologies (ICT) in education facilitates the shared creation of knowledge through learning communities (Vazquez-Cano, León-Urrutia, Parra-González \& López-Meneses, 2020). For its part, the European Commission (2018) has long considered that young citizens must possess certain key competencies to prepare them for adult life, to enable them to be active participants in society and to encourage continuous learning throughout their lifetimes. Digital competence is vital for activating today's citizens and must be adopted by all education systems across all areas (curricula, resources and support for training, updating competences by continuous learning, teacher training, equality, special needs, educational policies...).

A connectivity and ubiquity model of online learning could also foment a digital attitude based on sharing, constructing and exchanging digital resources that places collective intelligence at the service of knowledge and the enrichment of the educational community (Moreno, Leiva \& López-Meneses, 2017; Rauschnabel, Felix \& Hinsch, 2019). Technology is driving constant continuous transformation in people's lives, in the way they search for information, interact with others and generate content, as well as in resolving everyday problems; and technology used in education provides benefits and possibilities that affect traditional content transmission methods (López-Belmonte, Pozo, MoralesCevallos \& López-Meneses, 2019).

At the same time, a wide range of technologies is emerging in education, such as augmented reality, which is having a major impact on this field especially in 
higher education (Barroso \& Gallego, 2017; Fernández, 2017; López-Belmonte et al., 2019; Moreno \& Leiva, 2017).

The Horizon Reports of 2015 and 2016 predicted that AR would be used extensively in education ( 3 to 5 years) in the future. Different authors and reports (Barroso \& Gallego, 2017; Fernández, 2017; López-Belmonte et al., 2019; Moreno \& Leiva, 2017) have stated that AR would be potentially adopted in the next years in all educational stages. What is more, this emerging technology is spreading thanks to the use of mobile digital devices that enable everyone to access AR (Aznar-Díaz, Romero-Rodríguez \& Rodríguez-García, 2018; Blas, Vázquez-Cano, Morales \& López, 2019). Several authors (Bursalia \& Yilma, 2019; Cabero \& Barroso, 2016; Nadolny, 2017; Villalustre, 2020) have shown how AR represents the environment that integrates the real and the virtual worlds, combining digital and physical information in real time through technological devices. Augmented technology in education has huge potential, such as its application in the various learning stages (Bacca, Baldiris, Fabregat, Graf, \& Kinshuk, 2014; Garay, Tejada \& Maiz, 2017) its capacity to transfer experiences to different areas of education work with collaborative and constructivist methodologies (Blas et al., 2019; Cochrane, Narayan \& Antonczak, 2016) create simulated scenarios (Fabregat, 2012) enrich the use of printed material with a range of resources (Moreno \& Leiva, 2017), and transform the student into a technology designer (Cabero \& Barroso, 2016).

This immersive technological scenario also facilitates the creation of a constructivist educational context, and invigorates active teaching environments. Jee, Lim, Youn, and Lee (2014) stated that the tools traditionally used in the classroom can now be used in tandem with AR to draw daily reality closer to education, make learning more interesting and stimulating, and more relevant to students' everyday lives. Cabero, Leiva, Moreno, Barroso and LópezMeneses (2016) pointed to AR's potential to activate students' cognitive learning processes, develop cognitive and spatial skills regardless of age and academic level, and provide learning scenarios that are more motivating, collaborative and interactive.

RA is an educational instrument that allows students to be absorbed in immersive environments in which the simulated context is mixed with real objects and supports that certain more abstract contents could be explained and visualised in a more visual and enriched form. AR was first introduced as a training tool for airline and air force pilots during the 1990s (Caudell \& Mizell, 1992). Since Tom Caudell coined the term augmented reality in the early 1990s (Lee, 2012), this technology has experienced a great application in educational settings.

According to Dunleavy, Dede and Mitchell (2009), AR's most significant advantage is its "unique ability to create immersive hybrid learning environments that combine digital and physical objects, thereby facilitating the development of processing skills such as critical thinking, problem solving, and communicating through interdependent collaborative exercises" Augmented 
reality has a wide variety of fields of applications, such as art (Amakawa \& Westin, 2018), maths (Cai et al., 2019), medicine (ChanLin, ChiChan \& Wan, 2019), tourism (Kourouthanassis, Boletsis, Bardaki \& Chasanidou, 2015), entertainment or education (Villalustre, 2020). In this line and according to Chiang, Yang, and Hwang (2014a), AR technology provides relevant information, guidance to the students and supports motivation. On the other hand, this method is also perceived by students as more satisfying than classroom lessons (Marín-Díaz, 2017b; Villalustre, 2020). By displaying virtual elements alongside real objects, AR facilitates the observation of events which cannot easily be observed with the naked eye. Among other reasons, this is due to the ease of accessing information offered by this tool, as it is normally accessed by way of mobile devices (Murat \& Gökçe, 2017). In this sense, its combination with apps on mobile digital devices, such as a smartphone, allows teachers and students to have an educational tool inside and outside the classroom with which to simulate different educational experiences (VázquezCano \& Sevillano-García, 2018). As Chang, Wu, and Hsu (2013) and Jee et al. (2014) establish, AR could enhance students' motivation and promote situated learning, which may, in turn, result in students making more informed decisions.

In short, its use in education, as pointed out by different authors (Chang \& Hwang, 2018; Pejoska-Laajola, Reponen, Virnes \& Leinonen, 2017; Rauschnabel, He \& Ro, 2018), could provide different possibilities such as: a) To identify relevant information and avoid information that hinders the assimilation of significant information; b) Locate in reality the fundamental constitutive elements that allow the student to understand how it works; c) Being able to observe an object from different points of view and from different perspectives; d) To promote ubiquitous and mobile learning; e) Be able to have simulated and safe laboratory practices; f) Provide students with diverse learning systems that complement other, such as audiovisual and printed proposals; g) Turning the student not only into a content viewer, but also in the creation of proposals based on augmented reality; h) Complement other didactic approaches such as the Flipped Classroom methodology. AR employment outside the formal educational area can provide the citizen, in general, with great educational and entertainment possibilities (experiments, museums, etc.).

However, some authors (Cai, Liu, Shen, Liu, Li \& Shen, 2019; Han, Jo, Hyun \& So, 2015; Fernandez-Robles, 2018; Marín-Díaz, 2017a; Villalustre, 2020) stress $A R^{\prime}$ s limitations: teachers' shortcomings in technological competence, the lack of resources and the failure to provide clear objectives for learning with AR.

However, the limitations or disadvantages of AR are not the objective of this article(). The principal aim is to detect the possibilities of using AR in mobile applications with university students as this could improve or achieve the competencies needed for the final grade. This answers the hypothesis of the principal project that this article proposes: the use of AR with students will allow to detect the needs of students by using it to improve the student's competencies and create social attitudes for professional activities. 


\section{Materials and method}

This is a qualitative exploratory descriptive study. The methodological concept is based on a virtual collaborative investigation-action performed by university students to foment their generic and specific competences in the European Higher Education Area (Bogdan \& Biklen, 1992; Pool-Cibrian \& MartínezGuerrero, 2013). One of its objectives was to know the most useful and stimulating AR apps for educational purposes among those used in a seminar on immersive technologies in the academic years 2016-2017 and 2017-2018 for the university degree course in Social Education and the joint degree in Social Education and Social Work.

The qualitative analysis was based on a coding and categorisation process in two stages, descriptive and interpretative. The procedure was organised in three phases: Phase 1: 'Segmentation and identification of the units of meaning, and grouping in descriptive categories'; Phase 2: Construction of a system of emerging thematic nuclei and metacategories'; Phase 3: "Identification of qualitative dominions (sequential and transversal analysis of the metacategories'.

\subsection{Objectives}

The objectives were: 1) To know the new AR apps in educational settings, and the pedagogical potential of these AR apps in learning contexts. 2) To generate proactive attitudes in students towards augmented technologies. 3) To develop students' competencies in the use of these AR apps in didactic settings.

\subsection{Procedure}

This innovative immersive experience was developed in a seminar on emerging technologies in January and February 2016-2017, and again in 2017-2018. The two courses were Information Technologies and Communication in Social Education, both of which formed part of the first-year curriculum of the degree course in Social Education and the joint degree course in Social Education and Social Work, in the Faculty of Social Sciences at Pablo de Olavide University in Seville.

The AR apps used in the practical sessions with the students in the seminar were:

- Anatomy 4D. This AR app enables the student to explore inside the human body on a virtual journey to study the body's organs and systems (see Figure 1).

- Quiver. This is an augmented reality- and virtuality-based app that enables the user to colour printed sheets. These sheets can be photographed on any mobile device and then transformed, as the students generate augmented scenarios that enhance their learning processes (see Figure 2).

- Chromville. This app is similar to Quiver, with the same dynamic of printed sheets for colouring and immersive technology. The sheets act as markers for the creation of augmented fantasy settings via the mobile device's camera (see Figure 1). 
- Zookazam. With this app, the user can select from a wide range of animal species from our real habitat to create scenes from fables. It is similar in dynamic to the previous two and is available from Apple's app store and Google Play (see Figure 1).

\subsection{Sample}

The sample consisted of 231 students attending Pablo de Olavide University in Seville, with the following characteristics: 60 students ( 8 men, 58 women) in 2016-2017, and 58 students (5 men, 53 women) in 2017-2018, studying ICT and Social Education as part of their first-year joint degree course in Social Education and Social Work; 57 students (6 men, 51 women) in 2016-2017, and 56 students (4 men, 52 women) in 2017-2018, studying ICT and Social Education as part of their first-year degree course in Social Education.

The possible existence of a bias in the population with regard to the gender variable could be detected, but as Cheng and Chang (2006) and Gialamas, Nikiolopoulu, and Koutromanos (2013) point out, studies in the field of social sciences present an eminently feminised profile, affecting this variable worldwide, that is why we consider the non-existence of said bias in our sample

\subsection{Instruments}

At the end of February in both years, the students completed a questionnaire, The didactic use of AR, available at: https://goo.gl/forms/STik3sI9KdPzZi773) on challenges and didactics uses of AR. The questionnaire design was based on the theoretical considerations discussed by Barroso and Gallego (2017). To design the questionnaire, we have used a modified version, the two-round 'Modified Delphi'. In its implementation, we must pay special attention to a series of aspects: ensuring the anonymity of the participants, and, more specifically, their answers; using different iterations; establishing feedback control by the coordinating group; and using statistical techniques in the analysis of the responses (Rowe \& Wright, 1999).

To implement the Delphi method, five phases were applied:

1. Drafting of the first list of topics, with the descriptors that could be included.

2. First round of the Delphi study.

3. Analysis of the results obtained and the drafting of a new list.

4. Second round of the Delphi study.

5. Analysis of the results obtained and drafting of the validation scale.

Twenty-one participants were asked to evaluate them according to a scale of 1 to 5 , where 1 is equivalent to not at all important and 5 is very important. They were also asked to give their opinion on a series of aspects: a block of contents that they would eliminate or include or any items they would suggest eliminating, including or modifying within the proposed blocks of contents. The final mean and standard deviation of the dimensions of the questionnaire are shown in Table 1. 
Table 1: Mean and standard deviation of the dimensions of the questionnaire.

\begin{tabular}{|l|c|c|}
\hline Questionnaire dimensions & M & SD \\
\hline Augmented Reality: app characteristics & 4.30 & 0.73 \\
\hline Augmented Reality: educational functionalities & 4.08 & 0.65 \\
\hline Augmented Reality: advantages and limitations & 4,21 & 0.64 \\
\hline
\end{tabular}

One of the aims of the survey was to collate the students' opinions on the most useful and stimulating AR apps used in the immersive technology seminar. Our study specifically analysed the impressions of the 231 students of the AR apps used in the classroom, and their responses to an open question on the advantages of the didactic use of AR at university (see images 1 and 2).
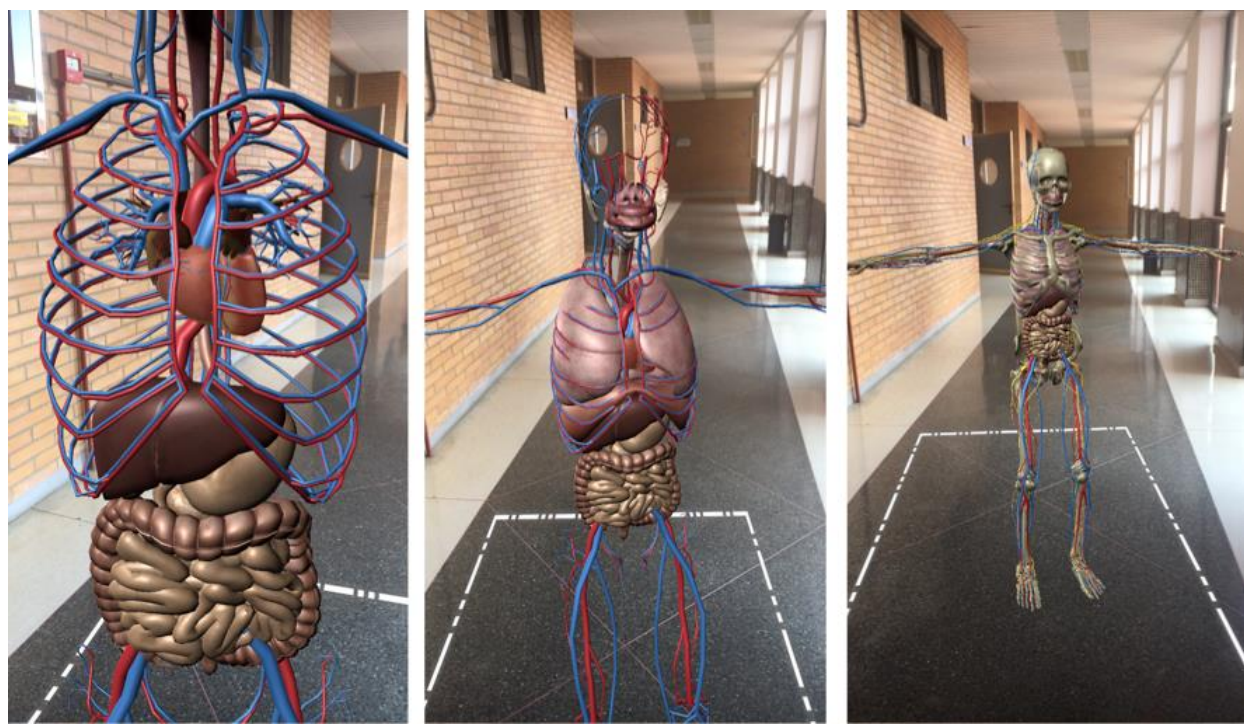

Image 1. Students using Augment and Anatomy 4D

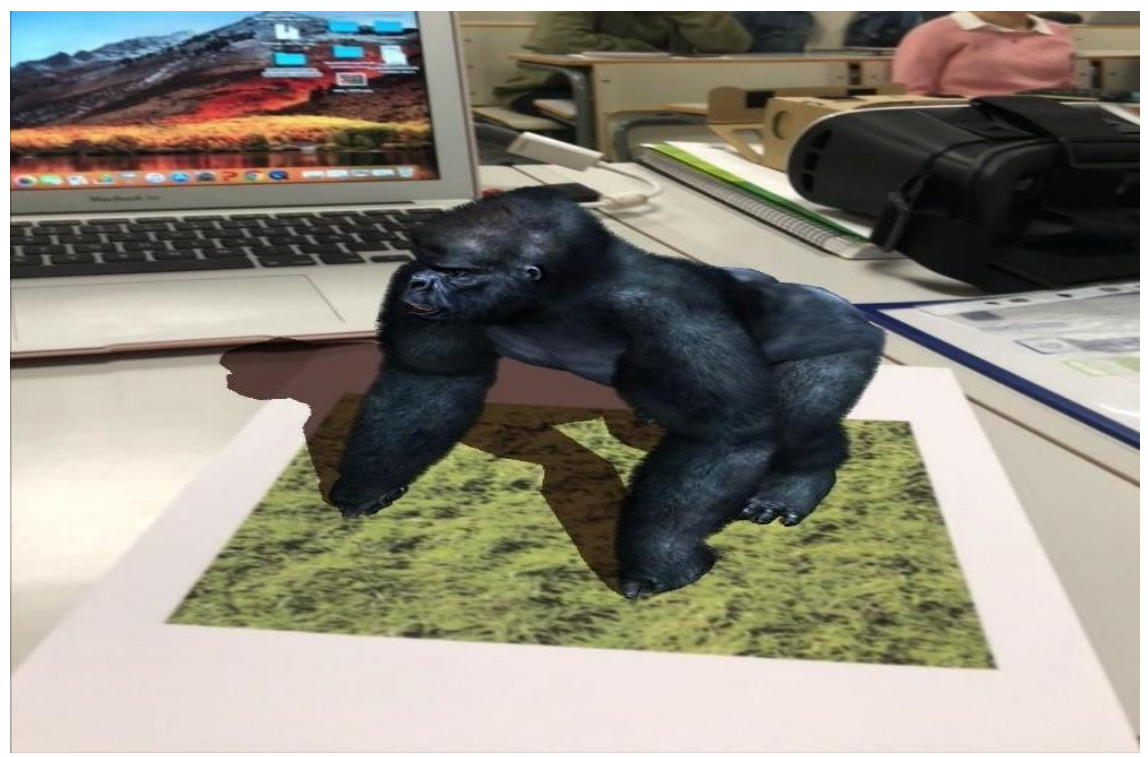

Image 2. Students using Quiver 


\section{Results}

This section presents the results of the analysis and interpretation of the contributions by the 231 students on the Social Education degree course and the Social Work and Social Education joint degree course between 2016-2018 with regard to the most useful and stimulating AR apps that they experimented with during the practical sessions of a seminar on emerging technologies.

According to the students on the Social Work and Social Education joint degree course in 2016-2017, the best AR apps to apply to significant learning processes were: Quiver (45\%); Zookazam (23\%), Chromville (17\%) and Anatomy 4D (15\%). The majority of students stated that Quiver was the most interesting from a didactic point of view, as it was easy to use, and highly intuitive and appropriate for young learners, enabling them to colour in the sheets then convert them into animated objects. Second-placed Zookazam was also easy to use and fast and helped students to learn about a wide range of animals. The students on the Social Education degree course (2016-2017) who tried out the AR apps during the emerging technologies seminar classified them for their motivational qualities as follows: Quiver (44\%), Zookazam (23\%), Chromville (14\%) and Anatomy 4D (19\%) (see images 1 and 2).

They stated that Quiver and Zookazam were the most interesting and educational for ease of use, usability and user-friendliness, as well as their clear orientation to educational processes. The results for the students on the Social Work and Social Education joint degree course in 2017-2018 were similar to those of their counterparts a year earlier for Quiver (45\%) and Zookazam (24\%). However, they differed from the previous year by placing Anatomy $4 \mathrm{D}$ in third place ahead of Chromville, at $17 \%$ and $14 \%$, respectively.

The students on the Social Education degree course in 2017-18 scored Quiver at $43 \%$ and Zookazam at $21 \%$, as the most interesting for use in a socio-educational setting due to their usability and applicability to a range of contexts for young learners.

Figure 1 presents the results of the frequencies for 2016-2018 in order to observe the oscillations about the most useful and innovative AR apps for educational processes that were tested by the participants in the emerging technologies seminar. 


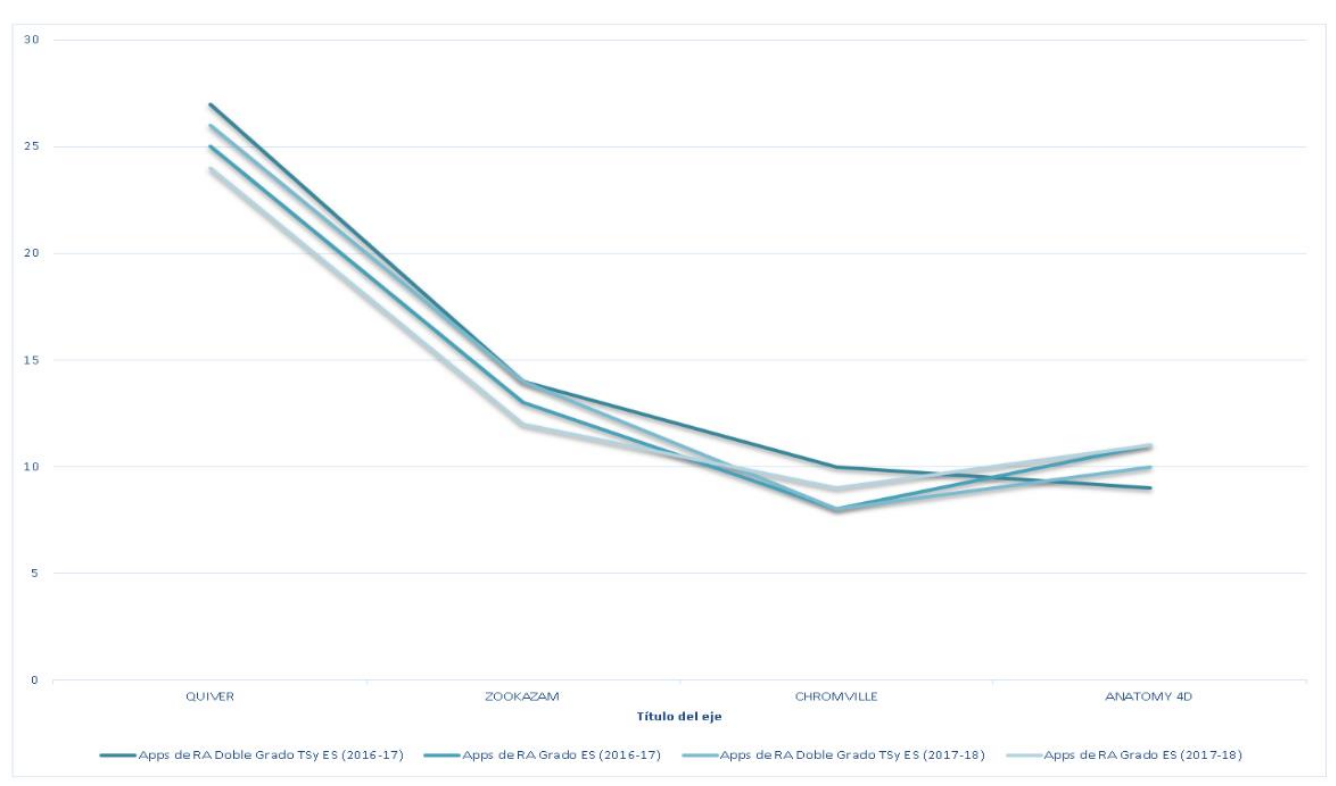

Figure 1. Comparison of frequencies for students at the emerging technologies seminar in 2016/17 and 2017/18.

It can be inferred that the students in both years who experimented with the AR apps at the emerging technologies seminar, as part of the course on ICT and Social Education, considered Quiver and Zookazam to be the best in terms of usability and ease of use, and were deemed the most appropriate for early learners to acquire new knowledge.

Students on both degree courses considered that these AR apps would provide educational scenarios that were more stimulating, collaborative and interactive, and would foment a more open type of education $(\mathrm{N}=159 / 68.8 \%)$. Similar results were found in teacher training for primary education (Moreno \& Leiva, 2017; Nielsen, Brandt \& Swensen, 2016; Villalustre, 2020). The motivation to create AR apps for educational processes has also been cited in diverse studies (Chiang, Yang \& Hwang, 2014a; Cochrane, Narayan \& Antonczak, 2016) and follows the same line as these results. Nevertheless, both studies considered that the focus of the students' attention should never be on how well they can handle the technology, but on the didactic function at the heart of that technology, in order for such apps to be applied correctly in both the learning and professional context (Cabero-Almenara, Vázquez-Cano \& López-Meneses, 2018; Rahman, Ling \& Yin, 2020).

The results from the students' perceptions on the relation between the advantages and disadvantages of $A R$ for the educational environment can be observed in the Atlas-Ti network in Figure 2. 


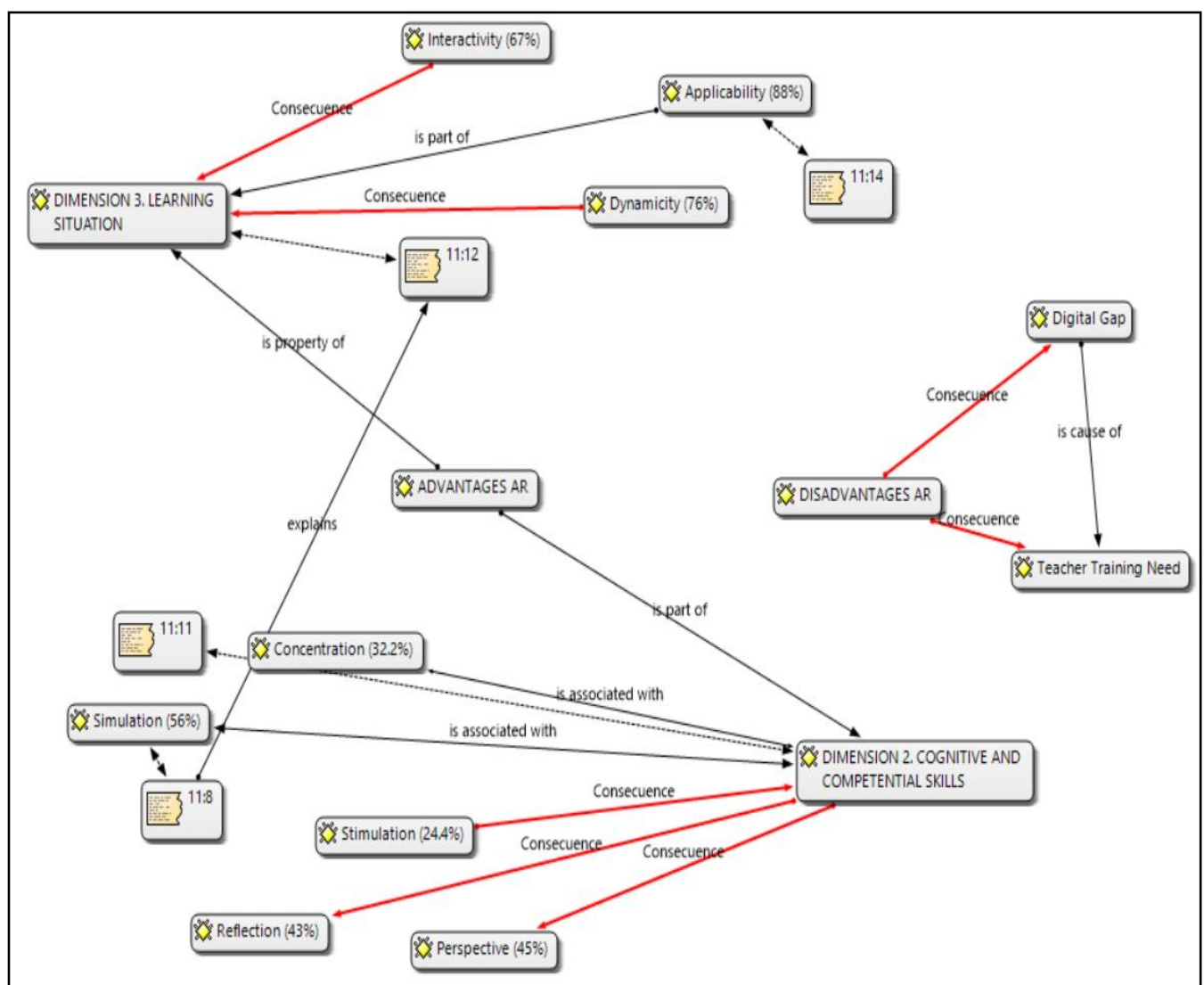

Figure 2. Atlas-Ti network. Advantages of AR applied to university student learning

\section{Discussion}

Firstly, the present study's findings are in line with those in other research (Aznar-Díaz et al., 2018; Cabero, Llorente \& Gutiérrez-Castillo, 2017; Cozar, de Moya, Hernández \& Hernández, 2015; Villalustre, 2020), in that the students reacted favourably towards the use of this type of emerging technologies because they considered them to be good motivational tools for learning (Chiang et al., 2014). AR apps also foment a proactive environment in teaching (Rauschnabel et al., 2019) and produce a high level of satisfaction among students (Chen, 2019). Likewise, as other investigations have testified (Barroso \& Gallego, 2017; Cabero et al., 2018), AR is useful for developing emerging competences in ICT, strengthening group work, and for discovering new useful, immersive didactic resources in social education and social work scenarios that were previously unknown to the majority of the students; this can generate new educational processes based on an investigative, constructivist and ubiquitous perspective. In this sense, we wish to emphasise that AR-based didactic activities are especially useful for pre-university and degree-level education, particularly in the Humanities and Social Sciences, because they allow students to access content in a different way to that frequently presented in a one-directional printed form that does nothing to motivate them or raise their ability for abstract thinking on the subject. AR apps allow content to be visualised in a way that is more creative, dynamic and real, which makes the teaching of a subject more attractive, innovative and stimulating for students at all levels of education (Marin-Díaz, 2017a,b; Moreno \& Leiva, 2017; Villalustre, 2020). 
The analysis of the AR didactic experience with the university students provided us with an initial conclusion that the use of objects based on augmented technology in higher education arouses considerable interest in students. Our study is in line with others that corroborate a high degree of satisfaction among students who use this technology and demonstrate a considerable increase in motivation when they are immersed in educational activities involving AR (Yip, Wong, Yick, Chan \& Wong, 2019).

In line with Fernández-Robles (2018), AR can be presented as a genuinely useful technology for training students at university, allowing them to work with active constructivist methodologies, providing them with the opportunity to visualise objects from different perspectives, facilitating the acquisition of knowledge that is difficult to access, enabling the presentation of simulated scenarios and enriching traditional printed material (Moreno, Franco-Mariscal \& Franco-Mariscal, 2018). This aspect could be very useful for students with any kind of disabilities. People with disabilities that negatively impact their social skills can use virtual reality to practise and improve their social skills (Bridges, Robinson, Stewart, Kwon \& Mutua, 2019; Cascales-Martínez, Martínez-Segura, Pérez-López \& Contero, 2017).

At the same time, the opinions of the Social Sciences students in this study show that the use of AR-based activities generates deeper reflection and a more positive attitude, and boosts the cognitive processes applied to the content in the Social Education and Social Work degree courses that they were taking. Also, it was interesting to see how students not only found AR to be applicable to the teaching-learning process, but also discovered how useful it was in the development of their own professional competencies as educators and social workers. In terms of applying AR as professionals in education and social work, the students emphasised that AR could be a particularly interesting tool in the treatment of drug addiction and its prevention among teenagers, in managing dementia-related disabilities in older people, and in the education of infants and adolescents within formal and informal educational settings. As Lindsey Getz (2018, p.6) points out, authors such as Patrick Bordnick are "currently exploring the ways in which we are training the next generation of social workers to prepare for disaster scenarios. If they never have any previous exposure, it's quite possible that they will present with anxiety when exposed to extreme situations or from a social work perspective, imagine the possibilities involved when students get an opportunity to interview a family and assess their needs post trauma - all in a virtual world."

on the other hand, without adequate teacher training in emerging technologies, their use in the classroom could even be counterproductive, acting as a brake on the development of competencies and content in the curriculum (Barroso \& Gallego, 2017; Blas et al., 2019; Marín-Díaz, 2017a,b). Likewise, it is important to be mindful of the resources available to educational institutions and students in order not to widen the digital divide or discriminate against students for lack of finance or access to technology. It is also important to ensure that this technology can be used for, and adapted to, the various special needs of students 
in the classroom. In this sense, the ease of use of virtual reality applications on smartphones favours the development of immersive learning spaces and provides access (Fombona, Vázquez-Cano \& Del Valles, 2018). What seems more important than the economic cost is the need to train teachers and professors in the new digital skills with this technology in order to take advantage of the educational and social potential of augmented reality applications to develop generic and transversal competencies among students (Blas et al., 2019; Marín \& Sampedro-Requena, 2019).

\section{Conclusions}

The principal conclusion of this research is that using this technology in the psychosocial treatment of these problems could help professionals to sharpen their competences and, at the same time, reinforce, support and improve the conditions and treatments of aspects identified in these at risk groups. In addition, AR was found to be useful for building emerging competences in ICT, for bolstering group work and for discovering new immersive didactic resources in social education and social work settings that the majority of students had not previously known about; such resources could help develop new educational processes from an investigative, constructivist and ubiquitous perspective. In this sense, the study emphasises that AR-based didactic activities can be particularly useful in pre-university and higher education settings in the fields of the Humanities and the Social Sciences, since they allow students to access content that improves on the one-directional printed form that often fails to stimulate or encourage students to think in a more abstract way about the subject. AR resources enable students to visualise content in a form that is more creative, dynamic and real, and teachers to present a didactic that is more attractive, innovative and motivational at all levels of education.

Despite these apparent benefits, we believe it is vital to go further in generating proposals and models for AR integration, with the development of AR firmly grounded in the educational context, taking into account subject areas and resources available, as well as the extent of teacher training in such technologies.

\section{Limitations}

This study has been approached from a qualitative approach of descriptive research in which the main purpose has been to know the opinion and perception of the university students about the educational possibilities of augmented reality for the development of content and competences in higher education. Future studies should contemplate the evaluation of the academic performance of students with the use of statistical inference techniques.

\section{Acknowledgement}

This study is part of the Project: Design, implementation and evaluation of mixed reality materials for learning environments (PID2019-108933GB-I00) funded by the Spanish Ministry of Science and Innovation. 


\section{References}

Amakawa, J., \& Westin, J. (2018) New Philadelphia: using augmented reality to interpret slavery and reconstruction era historical sites. International Journal of Heritage Studies, 24(3), 315-331. https:// doi.org/10.1080/13527258.2017.1378909

Aznar-Díaz, I., Romero-Rodríguez, J. M., \& Rodríguez-García, A. M. (2018). Virtual Reality mobile technology in education: a review of the state of scientific literature in Spain. EDMETIC, Revista de Educación Mediática y TIC, 7(1), 256-274. https://doi.org/10.21071/edmetic.v7i1.10139

Bacca, J., Baldiris, S., Fabregat, R., Graf, S., \& Kinshuk, J. (2014). Augmented Reality Trends in Education: A Systematic Review of Research and Applications. Educational Technology \& Society, 17(4), 133-149.

Barroso, J., \& Gallego, O. (2017). Learning resource production in Augmented Reality supported by education students. EDMETIC, Revista de Educación Mediática y TIC, 6(1), 23-38. https://doi.org/10.21071/edmetic.v6i1.5806

Blas, D., Vázquez-Cano, E., Morales , M., \& López, E. (2019). Use of augmented reality apps in University classrooms. Campus Virtuales, 8(1), 37-48.

Bogdan, R., \& Biklen, S.K. (1992). Investigación Cualitativa de la Educación. Needham Heights, MA: Allyn and Bacon.

Bridges, S. A., Robinson, O. P., Stewart, E. W., Kwon, D., \& Mutua, K. (2019). Augmented reality: Teaching daily living skills to adults with intellectual disabilities. Journal of Special Education Technology, 35(1), 3-14. https://doi.org/10.1177/0162643419836411

Bursalia, H., \& Yilma, R. M. (2019). Effect of augmented reality applications on secondary school students' reading comprehension and learning permanency. Computers in Human Behavior, 95, 126-135. https:// doi.org/10.1016/j.chb.2019.01.035

Cabero, J., \& Barroso, J. (2016). The educational possibilities of Augmented Reality. Journal of New Approaches in Educational Research, 5(1), 46-52. https:// doi.org/10.7821/naer.2016.1.140

Cabero, J., Leiva, J. J., Moreno, N., Barroso, J., \& López-Meneses, E. (2016). Realidad Aumentada y Educación. Innovación en contextos formativos. Octaedro: Barcelona.

Cabero, J., Llorente, M. C., \& Gutiérrez-Castillo, J. J. (2017). Evaluation by and from users: learning objects with Augmented Reality. RED, Revista de Educación a Distancia. 53, Artic. 4. http://dx.doi.org/10.6018/red/53/4

Cabero, J., Vázquez-Cano, E., \& López Meneses, E. (2018). Use of Augmented Reality Technology as a Didactic Resource in University Teaching. Formación Universitaria, 11(1), 25-34. https:/ / doi.org/10.4067/S0718-50062018000100004

Cabero-Almenara, J., Barroso-Osuna, J., Llorente-Cejudo, M. C., \& Fernández-Martínez, M. (2019). Educational uses of Augmented Reality (AR): Experiences in $\begin{array}{llll}\text { Educational Science. } & \text { Sustainability, }\end{array}$ https://doi.org/10.3390/su11184990

Cai, S., Liu, E., Shen, Y., Liu, Ch., Li, S., \& Shen, Y. (2019). Probability learning in mathematics using augmented reality: impact on student's learning gains and attitudes. Interactive Learning Environments, https://doi.org/10.1080/10494820.2019.1696839

Cascales-Martínez, A., Martínez-Segura, M.-J., Pérez-López, D., \& Contero, M. (2017). Using an augmented reality enhanced tabletop system to promote learning of mathematics: A case study with students with special educational needs. Eurasia Journal of Mathematics, Science and Technology Education, 13(2), 355-380. https://doi.org/10.12973/eurasia.2017.00621a 
Caudell, T. O., \& Mizell, D. W. (1992). Augmented reality: An application of heads-up display technology to manual manufacturing processes. Proceedings of the Twenty-Fifth Hawaii International Conference on System Sciences, 2, 659-669. 10.1109/HICSS.1992.183317

Chang, H., Wu, K., \& Hsu, Y. (2013). Integrating a mobile augmented reality activity to contextualize student learning of a socio scientific issue. British Journal of Educational Technology, 44(3), 95-99. https://doi.org/10.1111/j.14678535.2012.01379.x

Chang, S., \& Hwang, G. (2018). Impacts of an augmented reality-based flipped learning guiding approach on students' scientific project performance and perceptions, Computer $\& \quad$ Education, 226-239. https:// doi.org/10.1016/j.compedu.2018.06.007

ChanLin, L., ChiChan, K., \& Wan, Ch. (2019). An epistemological assessment of learning nutritional information with augmented reality. The Electronic Library, 37(2), 210224. https://doi.org/10.1108/EL-06-2018-0128

Chen, Y. (2019). Effect of Mobile Augmented Reality on Learning Performance, Motivation, and Math Anxiety in a Math Course. Journal of Educational Computing Research, 57(7), 1695-1722. https://doi.org/10.1177/0735633119854036

Chiang, T. H., Yang, S. J., \& Hwang, G. (2014). An augmented reality-based mobile learning system to improve students' learning achievements and motivations in natural science inquiry activities. Journal of Educational Technology \& Society. 17(4), 352-365

Cochrane, T., Narayan, V., \& Antonczak, L. (2016). A Framework for Designing Collaborative Learning Environments Using Mobile AR. Journal of Interactive Learning Research, 27(4), 293-316.

Cozar, R., de Moya, M., Hernández, J., \& Hernández, J. (2015). Emerging Technologies in Social Sciences Teaching. An Experience Using Augmented Reality in Teacher Training. Digital Education Review, 27, 138-153.

Dunleavy, M., Dede, C., \& Mitchell, R. (2009). Affordances and limitations of immersive participatory augmented reality simulations for teaching and learning, Journal of Science Education and Technology, 18(1), 7-22. https://doi.org/10.1007/s10956008-9119-1

European Commission (ed.) (2018). Proposal for a council recommendation on key competences for lifelong learning. Brussels. Retrieved from https:/ / bit.ly/2YsyGNz

Fabregat, R. (2012). Combining Augmented Reality and Adaptive E-Elearning Platforms. Enl@ce Revista Venezolana de Información, Tecnología y Conocimiento, 9(2), 69-78.

Fernández-Robles, B. (2018). The use of objects of learning of augmented reality in the universityeducation of primary education. International Journal of Educational Research and Innovation (IJERI), 9, 90-104.

Fombona Cadavieco, J., \& Vázquez-Cano, E. (2017). Posibilidades de utilización de la Geolocalización y Realidad Aumentada en el ámbito educativo. Educación XX1, 20(2), 319-342. https://doi.org/10.5944/educxx1.19046

Fombona Cadavieco, J., Vázquez-Cano, E., \& Del Valle Mejías (2018). Análisis de la geolocalización y realidad aumentada en dispositivos móviles, propuestas socioeducativas relacionadas con el entorno y las salidas de campo. Profesorado. Revista de Currículum y formación del profesorado, 22(4), 197-222. https://doi.org/10.30827/profesorado.v22i4.8413

Fombona, J., \& Vázquez-Cano, E. (2017). Possibilities of using geolocation and augmented reality in education. Educación XX1, 20(2), 319-342. https://doi.org/10.5944/educXX1.10852 
Garay, U., Tejada, E., \& Maíz, I. (2017). Valuation of the Educational Objects with Augmented Reality: Experience with Posgraduates Students. Píxel-Bit. Revista de Medios y Educación. 50, 19-31. https://doi.org/10.12795/pixelbit.2017.i50.01

Getz, L. (2018). Social Services Innovations: A Whole New World-Virtual Reality in Social Work. Social Work Today, 18(2), 6.

Han, J., Jo, M., Hyun, E., \& So, H. (2015). Examining young children's perception toward augmented reality-infused dramatic play, Education Technology Research Development. 63, 455-47. https://doi.org/10.1007/s11423-015-9374-9

Jee, H. K., Lim, S., Youn, J., \& Lee, J. (2014). An augmented reality-based authoring tool for E-learning applications. Multimedia Tools and Applications, 68, 225-235. https:// doi.org/10.1007/s11042-011-0880-4

Ketil, B. (2019). Understanding social and cultural aspects of teachers' digital competencies. Comunicar, 61, 9-19. https://doi.org/10.3916/C61-2019-01

Kourouthanassis, P., Boletsis, C., Bardaki, C., \& Chasanidou, D. (2015). Tourists responses to mobile augmented reality travel guides: The role of emotions on adoption behavior. Pervasive and Mobile Cumpoting, 18, 71-87. https://doi.org/10.1016/j.pmcj.2014.08.009

Lee, L. (2012). Augmented reality in education and training. TechTrends, 56(2), 13-21. https://doi.org/10.1007/s11528-012-0559-3

López Meneses, E., Leiva, J. J., \& Vázquez-Cano, E. (2017). The impact of personal interactions on the stress of school administrators: The validation and application of an assessment tool. Intangible Capital, 13(3), 499-522. doi: http://dx.doi.org/10.3926/ic.993

López-Belmonte, J., Pozo-Sánchez, S., \& Fuentes-Cabrera, A. (2019). Techno-pedagogical resources to support teaching: Augmented reality as a dynamic tool for the substitute teacher. International Journal of Educational Research and Innovation (IJERI). 12, 122-136.

Marín, V., \& Requena, B. (2019). La Realidad Aumentada en Educación Primaria desde la visión de los estudiantes. Alteridad, 15. 61-73. doi: 10.17163/alt.v15n1.2020.05.

Marín, V., \& Sampedro-Requena, B. (2020). La Realidad Aumentada en Educación Primaria desde la visión de los estudiantes. Alteridad, 15(1), 61-73. https://doi.org/10.17163/alt.v15n1.2020.05

Marín-Díaz, V. (2017a). The relationships between Augmented Reality and inclusive education in Higher Education. Bordón, 69(3). 125-142. https://doi.org/10.13042/Bordon.2017.51123

Marín-Díaz, V. (2017b). The Augmented Reality in the educational sphere of student of degree in childhood education. Case study. Pixel Bit, Revista de Medios y educación, 51, 9-24. http://dx.doi.org/10.12795/ pixelbit.2017.i51.01

Moreno, N. M., Leiva, J. J., \& López-Meneses, E. (2017). La realidad aumentada como tecnología emergente para la innovación educativa. Notandum. 44-45, 125-140.

Moreno, N., \& Leiva, J. J. (2017). Formative experiences in the educational use of augmented reality with students of primary education degree at the University of Malaga. EDMETIC, Revista de Educación Mediática y TIC, 6(1), 81-104. https://doi.org/10.21071/edmetic.v6i1.5809

Moreno, N., Franco-Mariscal, R., \& Franco-Mariscal, A. (2018). Augmented Reality in Chemistry: An Experience in Secondary Education Through Elements 4D. Journal of Science Education, 19(2), 71-94.

Murat, A., \& Gökçe, A. (2017). Advantages and challenges associated with augmented reality for education: A systematic review of the literature. Educational Research Review, 20, 1-11. https://doi.org/10.1016/j.edurev.2016.11.002 
Nadolny, L. (2017). The design of cognitive tasks in blended augmented reality and print documents. British Journal of Educational Technology, 48, 814-823. https://doi.org/10.1111/bjet.12462

Nielsen, B., Brandt, H., \& Swensen, H. (2016). Augmented Reality in science educationaffordances for student learning. Nordic Studies in Science Education, 12(2), 157174._https://doi.org/10.5617/nordina.2399

Pejoska-Laajola, J., Reponen, S., Virnes, M., \& Leinonen, T. (2017). Mobile augmented communication for remote collaboration in a physical work context. Australasian Journal of Educatinal Technology, 33(6), 11-25. https://doi.org/10.14742/ajet.3622

Pool-Cibrian, W. J., \& Martínez-Guerrero, J. I. (2013). Self-efficacy and Use of Strategies for Self-regulated Learning in University Students. Revista Electrónica de Investigación Educativa, 15(3), 21-37.

Rahman M. A, Ling L. S., \& Yin O. S. (2020) Augmented Reality for Learning Calculus: A Research Framework of Interactive Learning System. Computational Science and Technology. Technology, 603, 491-499. https://doi.org/10.1007/978-981-15-0058-9_47

Rauschnabel, P., He , J., \& Ro, Yo (2018). Antecedents to the adoption of augmented reality smart glasses: a closer look at privacy risks. Journal of Business Research, 92, 374-384. https://doi.org/10.1016/j.jbusres.2018.08.008

Rauschnabel, P. A., Felix, R., \& Hinsch, Ch. (2019). Augmented reality marketing: How mobile AR-apps can improve brands through inspiration. Journal of Retailing and Consumer Services, 49, 43-53. https://doi.org/10.1016/j.jretconser.2019.03.004

Rowe, G., \& Wright, G. (1999). The Delphi technique as a forecasting tool. Issues and analysis. International Journal of Forecasting, 15(4), 353-375. https:// doi.org/10.1016/S0169-2070(99)00018-7

Vázquez-Cano, E., \& Sevillano-García, M. L. (2018). Ubiquitous Educational Use of Mobile Digital Devices. A General and Comparative Study in Spanish and Latin America Higher Education. Journal of New Approaches in Educational Research, 7, 105-115. https://doi.org/10.7821/naer.2018.7.308

Vázquez-Cano, E., León-Urrutia, M., Parra-González, M. E., \& López-Meneses, E. (2020). Analysis of interpersonal competences in the use of ICT in the Spanish $\begin{array}{llll}\text { University } & \text { Context. } & \text { Sustainability, } & \text { 12(2), }\end{array}$ https://doi.org/10.3390/su12020476

Villalustre, L. (2020). Propuesta metodológica para la integración didáctica de la realidad aumentada en Educación Infantil. EDMETIC, Revista de Educación Mediática y TIC, 9(1), 170-187. https://doi.org/10.21071/edmetic.v9i1.11569

Yip, J., Wong, S., Yick, K., Chan, K., \& Wong, K. (2019). Improving quality of teaching and learning in classes by using augmented reality video. Computers $\mathcal{E}$ Education, 128, 88-101. https:// doi.org/10.1016/j.compedu.2018.09.014 